\title{
CD209 Antigen
}

National Cancer Institute

\section{Source}

National Cancer Institute. CD209 Antigen. NCI Thesaurus. Code C18489.

CD209 antigen (404 aa, $46 \mathrm{kDa}$ ) is encoded by the human CD209 gene. This protein plays a role in leukocyte adhesion and the mediation of antigen binding, uptake, and processing. 